\title{
Uptake and effects of americium-241 on a brackish- water amphipod
}

\author{
M. Hoppenheit ${ }^{1}$, C. N. Murray ${ }^{2} \&$ D. S. Woodhead ${ }^{3}$ \\ ${ }^{1}$ Biologische Anstalt Helgoland (Laboratorium Sülldorf); Wüstland 2, D-2000 Hamburg \\ 55, Federal Republic of Germany, \\ ${ }^{2}$ Commission of the European Communities, Joint Research Centre, Ispra Establish- \\ ment, Division of Chemistry; I-21020 Ispra, Varese, Italy, \\ and \\ ${ }^{3}$ Ministry of Agriculture, Fisheries and Food, Directorate of Fisheries Research, Fish- \\ eries Radiobiological Laboratory; Hamilton Dock, Lowestoft, Suffolk, NR32 1DA, \\ England
}

\begin{abstract}
The present paper reports the results of experimental work undertaken using the brackish-water amphipod Gammarus duebeni duebeni and the transuranium nuclide americium241. Data on the accumulation of this actinide showed that the larger fraction of the total body burden is associated with the exoskeleton. It was found that the body burden remained constant in the range $\mathrm{pH}$ 8.0-6.5 even though the water concentrations changed markedly. It would thus appear that the concept of a concentration factor should be re-examined and it is proposed that a factor should be defined in terms of environmental and chemical parameters which represent the bioavailable fraction of the actinide. The effect of americium on survival and moulting was studied at two activity concentrations; the dose rates and absorbed doses under the experimental conditions employed have been estimated. The differences in survival rates between the control and irradiated groups were statistically analyzed and the significant difference at the higher concentration is believed to be due to a synergism between physiological stress and radiotoxicity of americium rather than the chemical toxicity of the element.
\end{abstract}

\section{INTRODUCTION}

Due to the problems associated with the long-term storage of actinide-containing wastes, as well the increasing quantities of these isotopes within the nuclear fuel cycle, there is the possibility that their inventories within aquatic ecosystems could increase due to their release into the environment. It is now well accepted that these isotopes can be readily accumulated by aquatic biota and although information is accruing on existing environmental levels in water, sediments and biota, knowledge of their kinetics in aquatic organisms is scant.

An experimental laboratory programme studying the behaviour and effects of transuranium nuclides in estuarine and coastal waters on certain invertebrates is being undertaken with the following aims: (1) development of methods for determination of physical-chemical states of actinides in experimental media; (2) accumulation and 
retention in relation to environmental factors; (3) studies of alpha-radiation effects and (4) estimation of absorbed doses to the species under investigation.

The present paper reports the results of experimental work undertaken using the brackish-water crustacean Gammarus duebeni and the transuranium nuclide americium-241.

\section{MATERIAL AND METHODS}

Specimens of the brackish-water amphipod Gammarus duebeni duebeni Liljeborg were collected in the lake "Kleiner Kiel" (connected to the western Baltic Sea) in the city of Kiel and maintained in the laboratory for at least 14 days before use.

For each uptake experiment nine male Gammarus duebeni at various stages of the moulting cycle and all about the same size were placed separately in perforated plastic tubes (diameter $3.2 \mathrm{~cm}$, height $6.0 \mathrm{~cm}$ ) submerged in $200 \mathrm{ml}$ filtered water (Seitz-filter K 5). The contaminated water had been allowed to age for 8 days prior to the start of an experiment. After the addition of americium the medium was adjusted to $\mathrm{pH}$ 8.0. The experiments were performed at $10 \%$ salinity, $16 \pm 1{ }^{\circ} \mathrm{C}$, and LD $12: 12$. Each gammarid was fed 5-10 adult harpacticoid copepods once a week.

Counting was undertaken with $\mathrm{NaI}(\mathrm{Tl})$ crystals having a gamma-ray detection efficiency of $25 \%$. Samples were counted for variable time periods in order to obtain 5000 counts (counting error $\pm 1.4 \%$ ). The experimental procedure is described in detail in Murray et al. (1978).

Experiments have been undertaken parallel to those for accumulation on the radiation effects of americium-241 on the survival of juvenile Gammarus duebeni. Nine specimens were placed in each of three experimental containers (total 27 gammarids). An equal number served as control. All specimens were handled identically. In order to avoid bias in the allocation of treatment, the 54 specimens per experiment were allotted to the containers using random numbers. As in the uptake experiments each gammarid was placed in a perforated plastic tube and together with the other eight specimens was submerged in $200 \mathrm{ml}$ filtered brackish water $(10 \% \mathrm{~S})$. The contaminated water had been allowed to age and had been adjusted to $\mathrm{pH} 8.0$ immediately after contamination and again before the addition of the organisms. Mortalities recorded in each of the three beakers were pooled.

The results have been analyzed using log-probit transformation. Means and standard deviations were calculated from the regression equations. Analysis of variance showed considerable consistency of transformed data with the linear relationship found. The logarithms of mean survival times were compared by Student's $t$-test after having proved equality of variances by means of the F-test. This procedure is a simplified method approximating the evaluation by the maximum-likelihood analysis (cf. Kaufmann, 1966).

\section{RESULTS}

\section{Accumulation}

The dependence of the physical-chemical behaviour of actinides on $\mathrm{pH}$ (Murray \& Fukai, 1975) initiated experiments on the uptake of americium-241 by Gammarus duebeni $\delta$ at various $\mathrm{pH}$ values in the range from 8.2-6.5. Figure 1 shows the uptake 
by specimens that did not exhibit moulting during the experimental period of 100 days; maximum-minimum values are given. The initial uptake is rapid and the accumulated amount thereafter remains almost constant. The $\mathrm{pH}$ was controlled twice daily from Monday to Friday and if necessary adjusted. The initial concentration was $3.02 \mu \mathrm{Ci} \mathrm{I}^{-1}$ $\left(0.55 \mu \mathrm{Ci} 1^{-1}\right.$ on day 1$)$. The $\mathrm{pH}$ values chosen were 8.0 and 7.3 for days $0-26$ and $27-55$, respectively. Within this $\mathrm{pH}$ range the water activity steadily decreased over the 55 days. A further decrease after day 55 to $\mathrm{pH} 6.5$ led to an increase in water activity with no visible change in the accumulated body burden of the gammarids. On day 71 the $\mathrm{pH}$ was readjusted to 7.3 as earlier and was again followed by a steady decrease in water activity until day 100 when the experiment was stopped. The changes in water activities from days $0-55$ are considered to be due to the adsorption of americium to the container wall or to sedimented particulate material. Under the more acid conditions ( $\mathrm{pH}$ 6.5) a

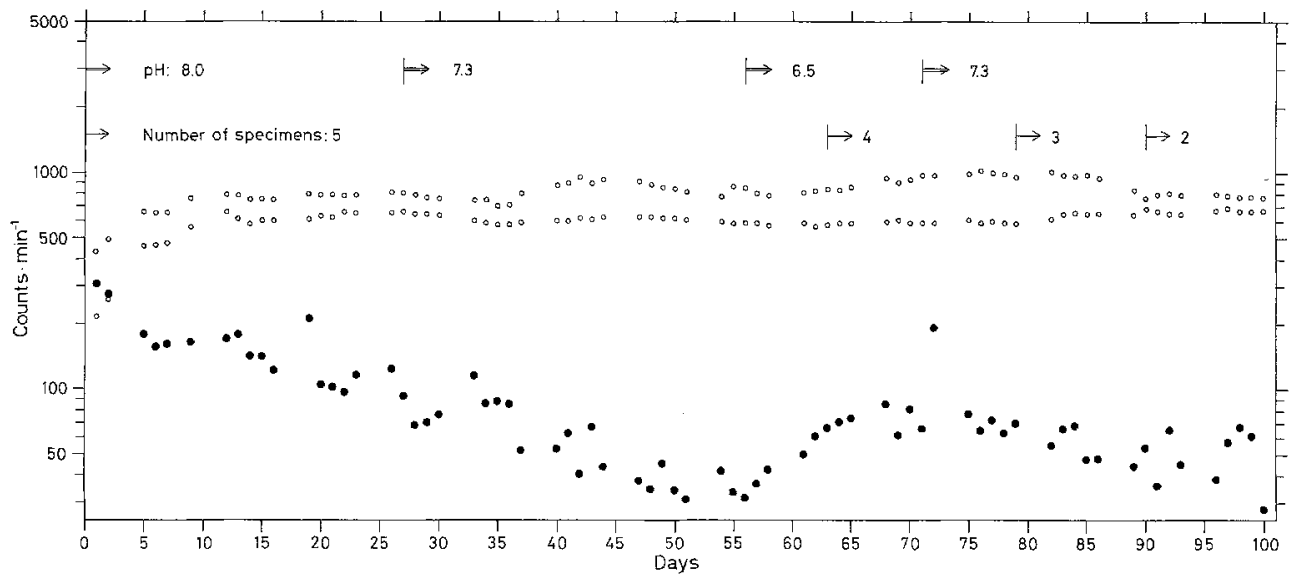

Fig. 1. Gammarus duebeni. Uptake of ${ }^{241} \mathrm{Am}$ from aged water by 5 specimens that had not moulted during the experimental period. Maximum and minimum values are given by 0 , water activity per $\mathrm{ml}$ by

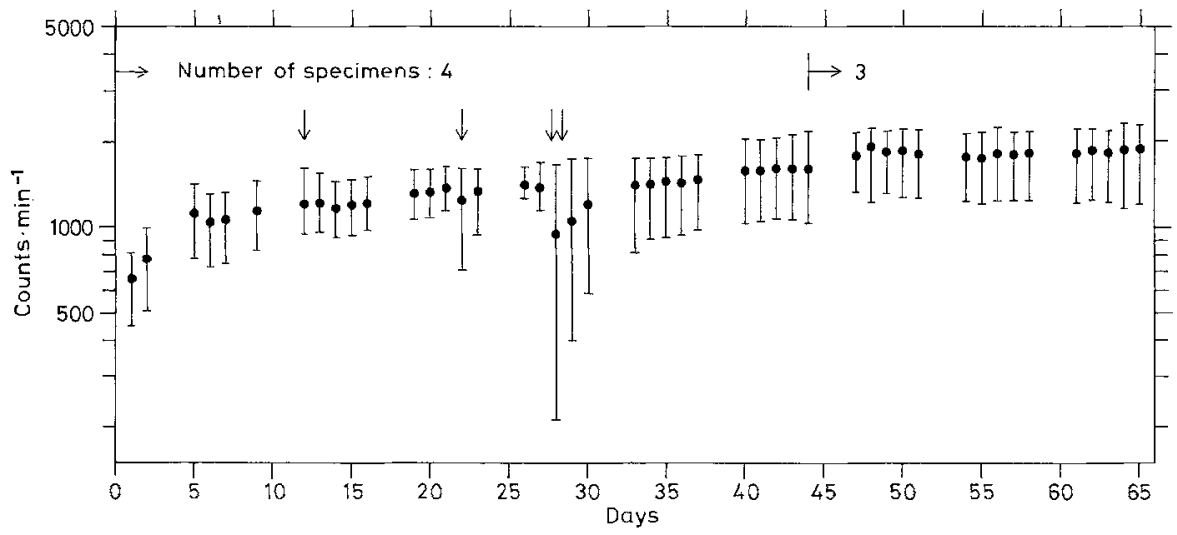

Fig. 2. Gammarus duebeni. Uptake of ${ }^{241} \mathrm{Am}$ from aged water by 4 specimens that had moulted during the experimental period. Closed circles and bars represent mean and range. Ecdyses are indicated by arrows 


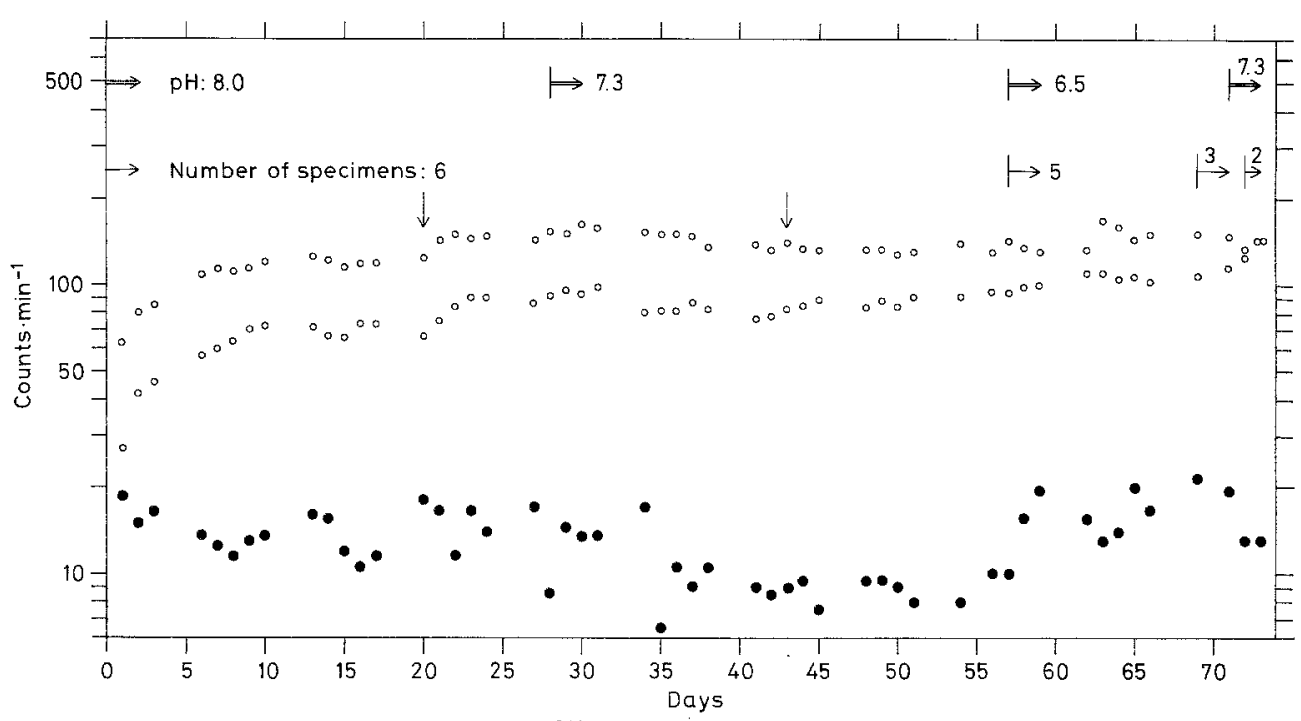

Fig. 3. Gammarus duebeni. Uptake of ${ }^{241} \mathrm{Am}$ from aged water by 6 specimens. Maximum and minimum values are given by 0 , water activity per $\mathrm{ml}$ by $\bullet$, ecdyses are indicated by arrows

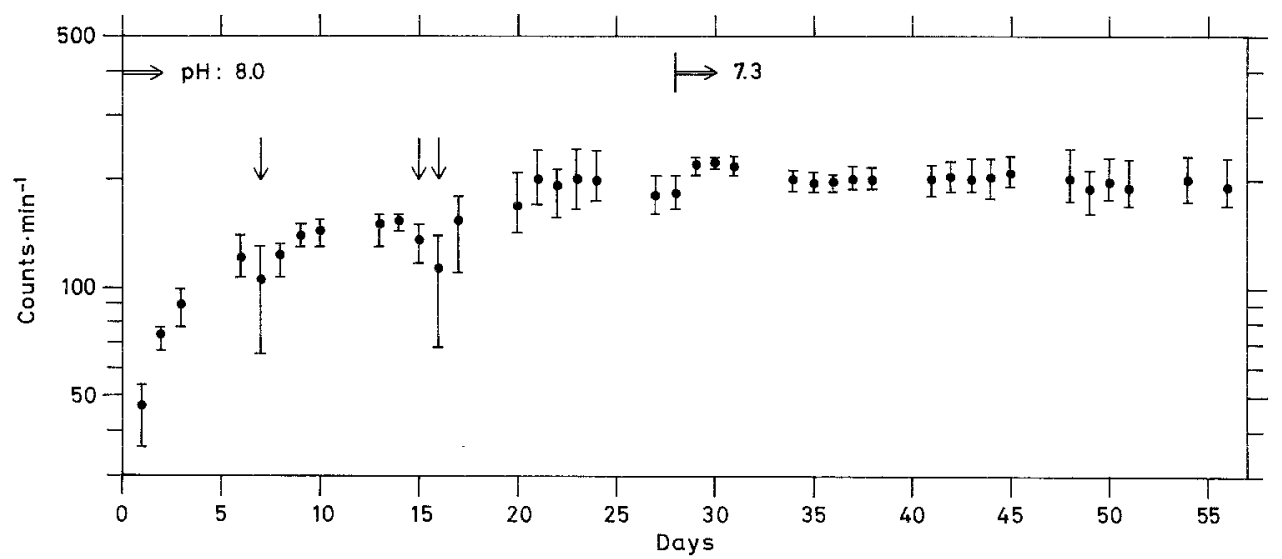

Fig. 4. Gammarus duebeni. Uptake of ${ }^{241} \mathrm{Am}$ from aged water by 3 specimens that had moulted up to day 16. Closed circles and bars represent mean and range. Ecdyses are indicated by arrows

desorption process appears to occur thereby increasing the water activity. On increasing the $\mathrm{pH}$ (7.3) again a further sorption process takes place.

The results would appear to indicate that the body burden of the organisms is not dependent on $\mathrm{pH}$ in the range 8-6.5. In two specimens, moulting was actually observed during uptake and the exuviae were measured immediately afterwards. It was found that 56 and $85 \%$ of total body activity (wet weight), respectively, was bound to the moults.

The concentration factor reached by the individuals of Figure 1 which did not moult during the course of the experiment was found to be 37 (wet weight basis) ranging from 25-56 in the period from days 12 to 16 at $\mathrm{pH}$ 8.0. The three specimens which moulted after reaching an activity plateau on days 12-16 arrived at a higher concentration factor of about 62 (Fig. 2). These results are in agreement with earlier findings of Murray et al. 


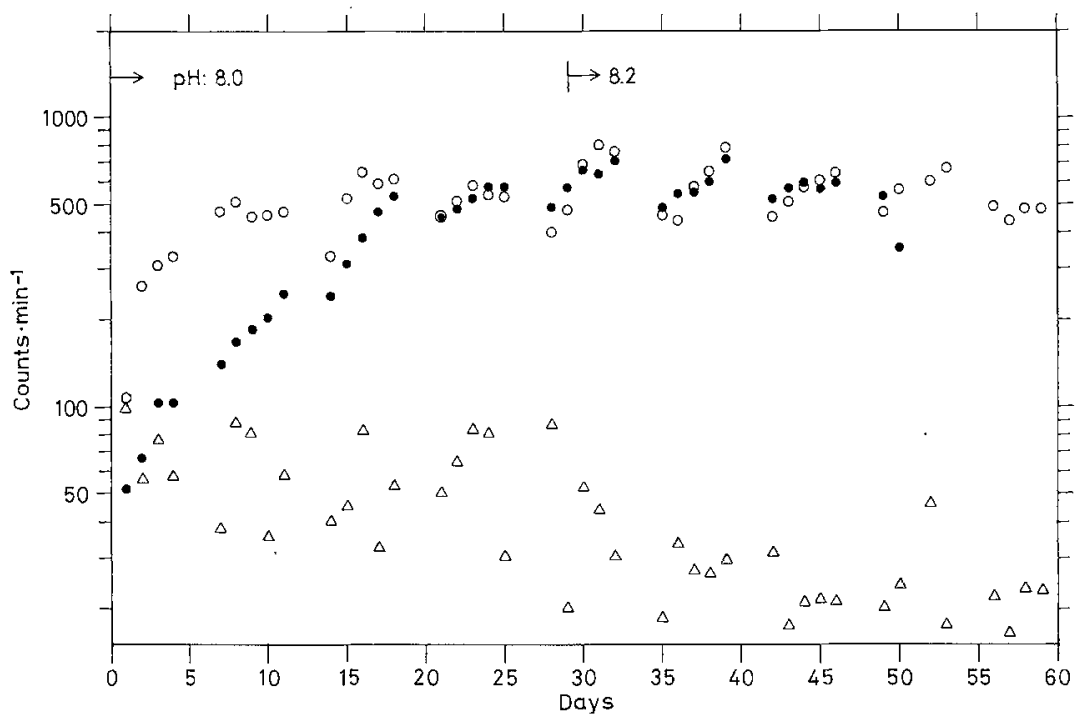

Fig. 5. Gammarus duebeni. Uptake of ${ }^{241} \mathrm{Am}$ from aged water by 2 specimens that had moulted during the experimental period. Water activity per $\mathrm{ml}$ is given by open triangles

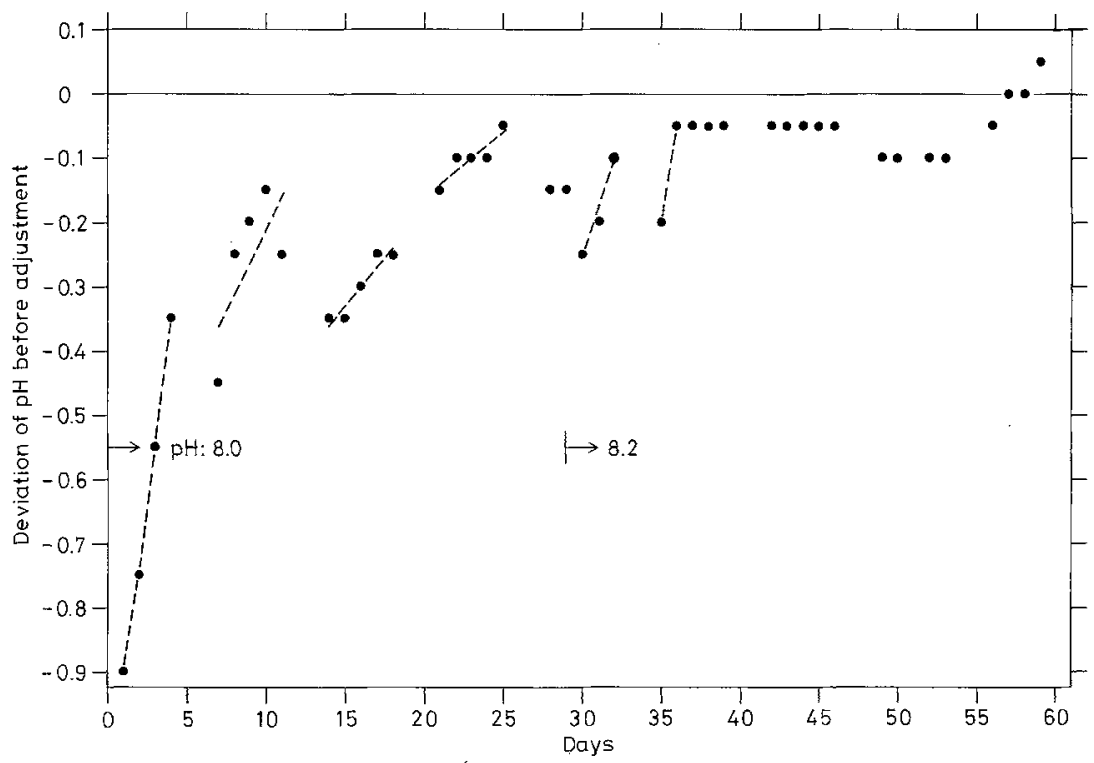

Fig. 6. Deviation of $\mathrm{pH}$ before adjustment. Trends are indicated by dotted lines

(1978). Further, the absolute body burden after moulting, compared with those animals which did not moult, was higher. For example between days 54 and 58 the absolute body burden was $3.22 \mathrm{nCi}$ on average per individual (weight ranges for both groups $100-140 \mathrm{mg}$ ) for moulted individuals and $1.28 \mathrm{nCi}$ for individuals that did not moult, a difference of 2.5 times. Metabolic processes associated with exoskeleton formation may account for this difference. 
In gammarids, death often occurs at an ecdysis or shortly after an ecdysis has taken place (cf. Hoppenheit, 1969); thus moulting seems to represent a critical step in the life of every individual. If an individual does not have a good chance of further survival after moulting occurs, the uptake of americium will be less than in animals which continue to survive without difficulties. All gammarids which died during the experiments showed a loss in activity before death.

The above described experiment was repeated with an americium concentration about 10 times lower $\left(0.033 \mu \mathrm{Ci} 1^{-1}\right.$ on day 1$)$. Figure 3 presents the uptake in 6 specimens and the variation in water activity. The two individuals which moulted on days 20 and 43 , indicated by arrows, showed no deviation in uptake from those which did not moult. The concentration factor for days 13-17 was found to be 78 on average (range: $51-113$ ), about twice that found in the first experiment. It should be noted that the gammarids in the second experiment were on average lighter by a factor of 0.8 . Those specimens which moulted during the first 16 days after the start of the experiment (Fig. 4) reached a higher body burden than those which did not moult or which moulted after this period $(0.29 \mathrm{nCi}$ as compared with $0.19 \mathrm{nCi}$ per specimen for days $48-51$ ). The variation in water activity is similar to that in the preceding experiment. The observations were terminated on day 74 due to a defect in the temperature-controlling system.

A third uptake experiment was undertaken to demonstrate whether an increase in $\mathrm{pH}$ would lead to a change in accumulation. The uptake was studied at a $\mathrm{pH}$ of 8.2. A decrease in $\mathrm{pH}$ to 8.0 after 37 days did not result in a change of the accumulated amount of americium. For days $49-53$ the total body burden was $0.31 \mathrm{nCi}$ per specimen (range: $0.21-0.38 \mathrm{nCi})$; that is 1.6 times more than in the preceding experiment $(0.19 \mathrm{nCi}$ per specimen, range: $0.15-0.24 \mathrm{nCi}$ ). It has to be taken into account that the water activity was slightly higher in the latter experiment $\left(0.012-0.039\right.$ and $0.013-0.052 \mu \mathrm{Ci} \mathrm{l}^{-1}$, respectively). In a further study the $\mathrm{pH}$ was kept constant at 8.0 for 28 days and then raised to 8.2. No change in uptake was observable. However a decrease in the amount of accumulated americium during weekends followed by an increase from Monday to Friday was noticed in individuals that did not moult during the experimental period.

This phenomenon is demonstrated by two examples in Figure 5. Figure 6 shows the corresponding deviations in $\mathrm{pH}$ before daily adjustment. Trends are indicated by dotted lines. In the course of the experiment deviations from the chosen $\mathrm{pH}$ values became continuously smaller and the saw-toothed characteristic of curves of Figure 5 disappeared. From days 39 to 42 there was no measurable reduction of $\mathrm{pH}$ at an accuracy of measurement of $\mathrm{pH} 0.1$. Since, nevertheless, a decrease in accumulated activity during the weekend and an increase from Monday to Friday (cf. Fig. 5) was observed, it is assumed that rather small changes in $\mathrm{pH}$ (less than 0.1) are able to influence the amount of activity adsorbed. The conjecture that an adsorption process is responsible is supported by the observation that only those specimens which did not moult exhibited the sawtoothed characteristic. The americium taken up by the calcifying skeleton following ecdysis seems to be more strongly associated with the shell. The phenomenon described might, therefore, be explained on the basis of simple adsorption. The saw-toothed characteristic was only found if the $\mathrm{pH}$ deviated from adjusted values of 8.0 or 8.2 in the negative direction. Positive deviations were of no influence. 


\section{Effect on survival}

Two experiments were performed to study the radiation effects of americium-241 on the survival of juvenile Gammarus duebeni.

During the first experiment the americium water activity ranged from $1.46-0.15 \mu \mathrm{Ci}$ $\mathrm{1}^{-1}$ (Fig. 7), equivalent to a metal concentration of $450-46 \mathrm{ng} \mathrm{l}^{-1}$. Based on observations of the activity accumulated by juveniles of the same size (average weight of irradiated group $23 \pm 7 \mathrm{mg}, 1$ sigma) at an average activity of $0.15 \mu \mathrm{Ci}^{-1}$ (range: $0.08-0.25 \mu \mathrm{Ci}^{-1}$ ), the body burdens were estimated to be $3.1 \mathrm{nCi}$ (range: $1.3-8.5 \mathrm{nCi}$ ), equivalent to about $1 \mathrm{ng}$ Am.

As can be seen in Figure 7 the hydrogen ion concentration dropped from $\mathrm{pH} 8.0$ (day 0 ) to about $\mathrm{pH} 7.2$ over the first five days. It then remained reasonably constant until day

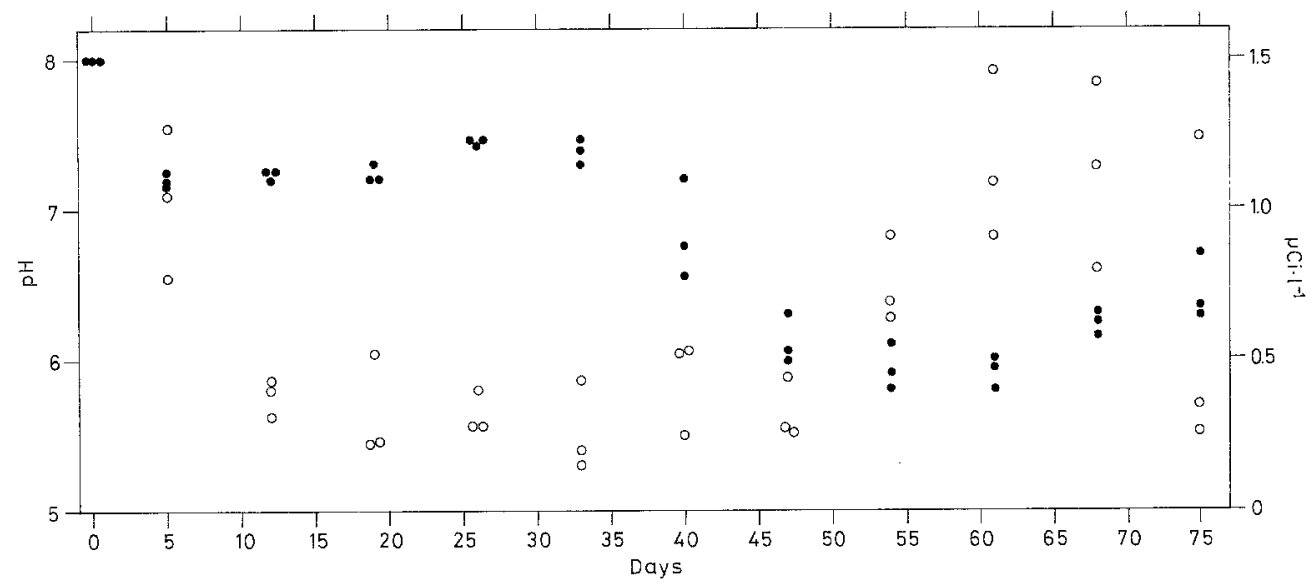

Fig. 7. First irradiation experiment. $\mathrm{pH}$ values for each of the three experimental containers are given by $\bullet$, water activity per $\mathrm{ml}$ by 0

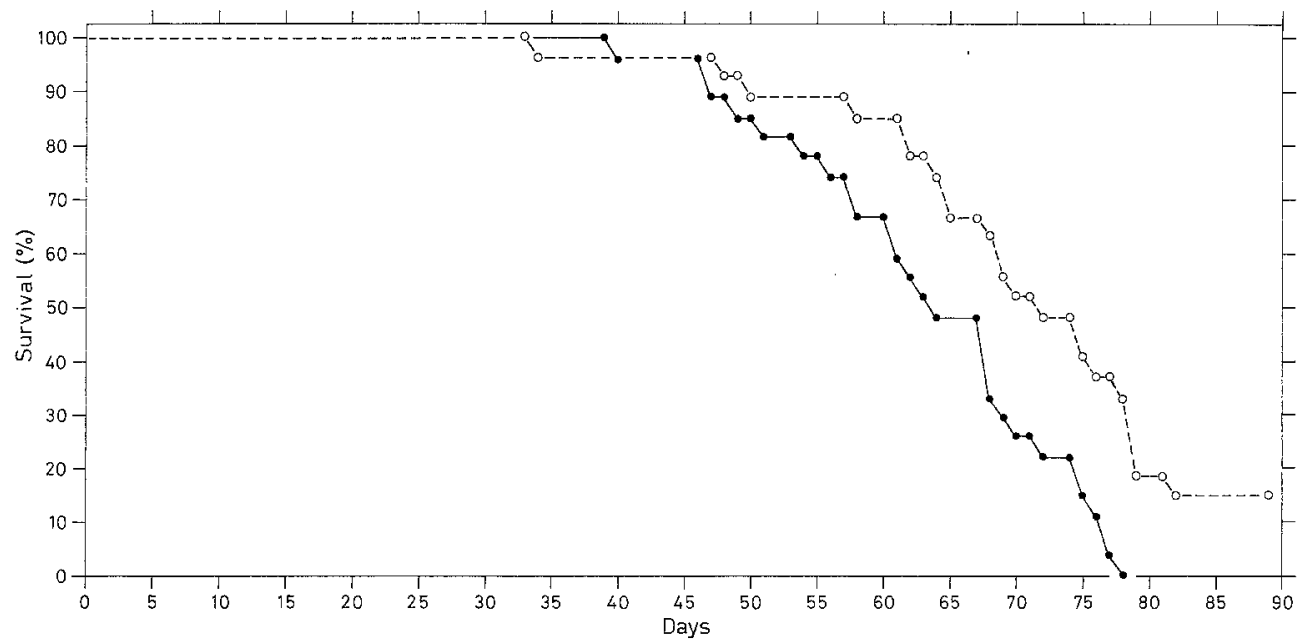

Fig. 8. Gammarus duebeni. Percentage survival of irradiated ( $\bullet$ ) and control groups $(0)$ of juvenile individuals. 27 specimens in each group 


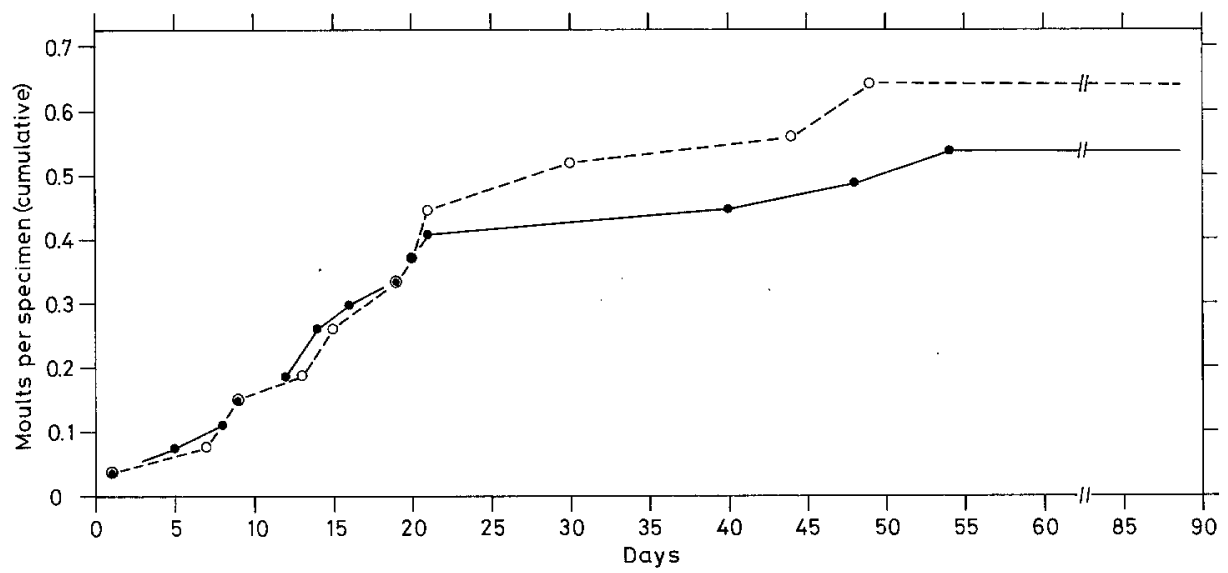

Fig. 9. Gammarus duebeni. Moults per specimen cumulative over experimental period in first irradiation experiment

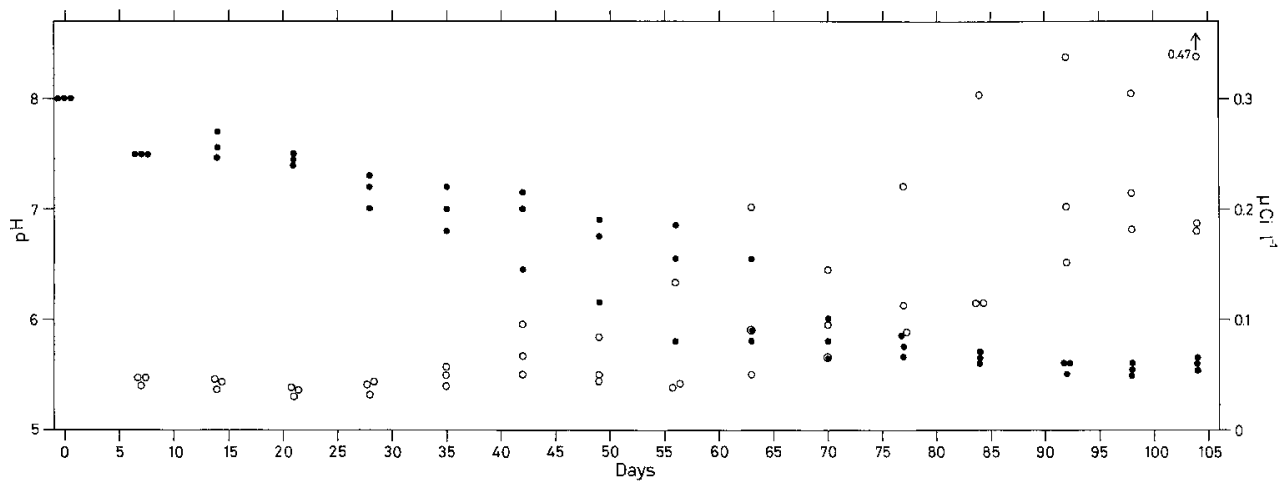

Fig. 10. Second irradiation experiment. $\mathrm{pH}$ values for each of the three experimental containers are given by $\bullet$, water activity per $\mathrm{ml}$ by 0

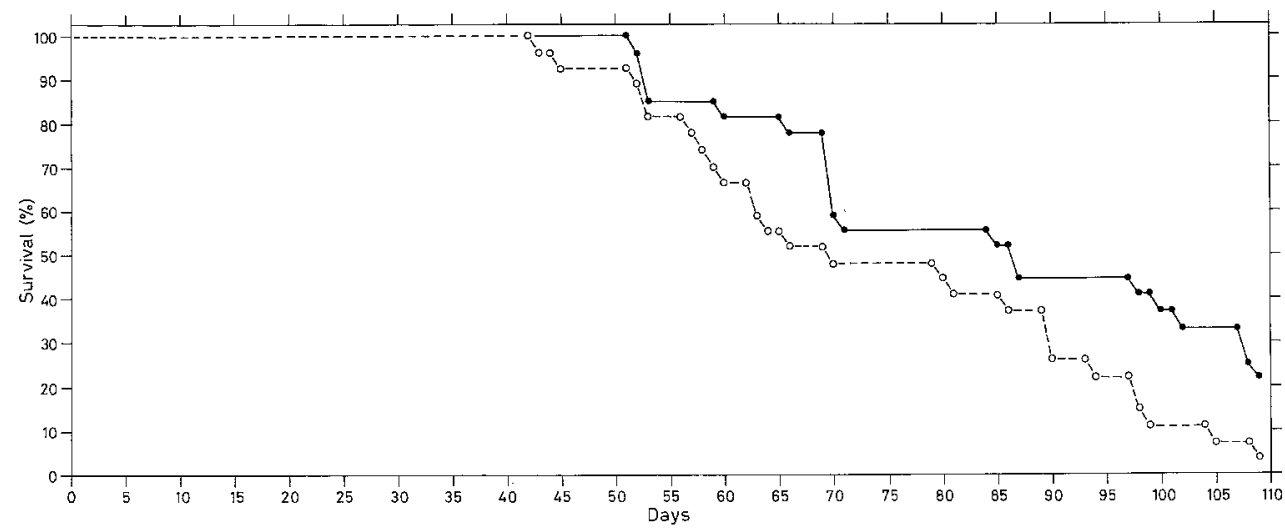

Fig. 11. Gammarus duebeni. Percentage survival of irradiated ( $\bullet$ ) and control groups $(0)$ of juvenile individuals. 27 specimens in each group 
33 after which it decreased till day 54. This decrease may indicate a change in water quality brought about by, among other factors, the amount of food offered to individuals living in small volumes of water. The gammarids were fed twice a week till day 50 with either commercially available fish food or spinach; they were then given food only once a week. This change in the feeding cycle after day 50 was followed by a slow increase in $\mathrm{pH}$ until day 75. It can be seen by comparison with Figure 1 that a similar trend in water activity occurs in the two experiments. A decrease in $\mathrm{pH}$ to around 6.0-6.5 is accompanied by an increase in the water activity.

The simultaneous appearance of high mortality and lowered $\mathrm{pH}$ in both groups (Fig. 8) leads us to assume that the observed effect on survival is caused by a synergism between radiation and physiological stress due to unfavourable experimental conditions. The difference between groups was found to be significant at the $99 \%$ level (onetailed). The mean survival times were calculated according to Sachs $(1974, \mathrm{p} .88)$ to be 64 and 72 days, the $95 \%$ confidence intervals extending from 66 to 75 and 58 to 68 days, for the control and irradiated groups, respectively.

Murray et al. (1978) observed a cessation of moulting in specimens exposed to americium-243. They proposed that this might be due to irradiation. The present experiments show that both in control and irradiated groups moulting rates, as shown in Figure 9, were identical until day 21; thereafter a slight difference in the rates for the two groups appears. The rate for the irradiated group was somewhat slower than for the control group. After days 49 and 54 no further moulting was observed for the duration of the experiment. This cessation of moulting in both groups is probably, therefore, ascribable to the general experimental conditions.

In the second experiment the concentration of americium ranged from 0.03 to 0.47 $\mu \mathrm{Ci}^{-1}$ (Fig. 10). Twice a week the gammarids were fed 3 harpacticoid copepods; once a fortnight they received spinach instead of copepods. In spite of the changed feeding regimen the $\mathrm{pH}$ dropped from an initial value of 8.0 to 5.5. Again a decrease in $\mathrm{pH}$ is accompanied by an increase in water activity. Differences in survival (Fig. 11) are not significant. The mean survival times were estimated to be 75 and 90 days, the $95 \%$ confidence intervals extending from 63 to 82 and 71 to 98 days, for the control and irradiated groups, respectively. The body burdens were estimated to be $0.37 \mathrm{nCi}$ (range: $0.15-0.78 \mathrm{nCi}$ ).

Observation of the moulting rates yielded a similar pattern to that obtained in the first experiment (cf. Fig. 9), the number of moults per specimen being less in the irradiated group.

\section{Dosimetry}

Accurate estimates of absorbed dose rate or total absorbed dose depend on a knowledge of the precise distribution of the source of radiation in relation to possible targets and its variation in time together with an appropriate point source dose distribution function. In the present instance, a lack of information as to the identity of the target or targets and limited information as to the differential accumulation and distribution of americium-241 by the amphipods necessitates various simplifying assumptions. The accumulation of americium-241 in all compartments within the amphipod has been assumed to have the same time-dependency as determined for whole body uptake by juveniles, i.e. 


$$
C(t)=C_{s s}\left(1-\exp \frac{-0.693 t}{t_{1 / 2}}\right)
$$

where $C(t)$ is the concentration at time $t_{i}$

$\mathrm{C}_{\mathrm{ss}}$ ist the steady state concentration; and

$\mathrm{t}_{1 / 2}$ is the time constant of the accumulation process, in this case 1.4 days. The description of the differential distribution of the radionuclide within the amphipod has been limited to two compartments: the exoskeleton with a uniform distribution of activity over the external surface and soft tissue with a uniform distribution of activity throughout the volume. The data relevant to the dose calculations are summarized in Table 1.

Table 1. Basic data for dose calculations

\begin{tabular}{|llc|}
\hline & Experiment I & Experiment II \\
\hline Mean water concentration (pCi ml ${ }^{-1}$ ) & $5.92 \times 10^{2}$ & $8.50 \times 10^{1}$ \\
Mean weight of amphipods (g) & $(2.3 \pm 0.7) \times 10^{-2}(2.5 \pm 0.8) \times 10^{-2}$ \\
Estimated surface area of amphipods (cm ${ }^{2}$ ) & 1.6 & 1.6 \\
Weight (g) of exoskeleton (19\% of body weight) & $4.4 \times 10^{-3}$ & $4.8 \times 10^{-3}$ \\
Weight (g) of soft tissue (81\% of body weight) & $1.86 \times 10^{-2}$ & $2.02 \times 10^{-2}$ \\
Estimated equilibrium body burden (pCi) & $3.1 \times 10^{3}$ & $3.7 \times 10^{2}$ \\
Radioactivity (pCi) in exoskeleton (61\% of body burden) $1.9 \times 10^{3}$ & $2.3 \times 10^{2}$ \\
Radioactivity (pCi) in soft tissue (39\% of body burden) & $1.2 \times 10^{3}$ & $1.44 \times 10^{2}$ \\
Concentration of radioactivity in exoskeleton (pCi cm & $-2) 1.2 \times 10^{3}$ & $1.4 \times 10^{2}$ \\
Concentration of radioactivity in soft tissue (pCi g ${ }^{-1}$ ) & $6.5 \times 10^{4}$ & $7.1 \times 10^{3}$ \\
Mean survival time (days) & 64 & 90 \\
\hline
\end{tabular}

The absorbed dose rate and the total absorbed dose have been calculated for two targets: firstly, cells in the soft tissue effectively surrounded by an infinite source of uniformly distributed americium-241, and secondly, the nucleus of an epidermal cell 10 $\mu \mathrm{m}$ diameter adjacent to cuticle of thickness $5.8 \mu \mathrm{m}$ (this being the estimated weighted mean cuticle thickness for the whole body; measurements taken from fixed material). It has been assumed that the nucleus is centrally situated within the cell and therefore 10.8 $\mu \mathrm{m}$ from the radioactivity adsorbed to the external surface of the cuticle.

\section{Soft tissue}

The dose rate in an effectively infinite volume (ie. dimensions $\gg$ than the range of the radiation) of tissue uniformly contaminated with radioactivity is

$$
\mathrm{D}_{\alpha}(\infty)=2.31 \overline{\mathrm{E}}_{\alpha} \mathrm{C}_{\mathrm{ss}} \mu \mathrm{rad} \mathrm{h}^{-1},
$$

where $\overline{\mathrm{E}}_{\alpha}$ is the mean energy of the $\alpha$-particles in $\mathrm{MeV}$

and $\mathrm{C}_{\mathrm{ss}}$ is the steady state concentration in $\mathrm{pCi} \mathrm{g}^{-1}$.

The total absorbed dose over the mean survival time is

$$
D_{\alpha}\left(T_{s}\right)=\int_{0}^{T_{s}} 2.31 \bar{E}_{\alpha} C_{s s}\left(1-\exp \frac{-0.693 t}{t_{1 / 2}}\right) \times 24 d t
$$


These expressions give

$$
\mathrm{D}_{\alpha}(\infty)=0.77 \mathrm{rad} \mathrm{h}^{-1} \text { and } \mathrm{D}_{\alpha}\left(\mathrm{T}_{\mathrm{s}}\right)=1150 \mathrm{rad}
$$

respectively for experiment $I$; and

$$
\mathrm{D}_{\alpha}(\infty)=0.08 \mathrm{rad} \mathrm{h}^{-1} \text { and } \mathrm{D}_{\alpha}\left(\mathrm{T}_{\mathrm{s}}\right)=178 \mathrm{rad}
$$

respectively for experiment II.

\section{Epidermal cell nucleus}

For $\alpha$-particles with ranges in tissue of the order of a few tens of microns $(\mu \mathrm{m})$ it is clear that the distribution of the source should be known on this scale for an accurate estimation of radiation dose. Since the data do not have this degree of detail further simplification of the dosimetry model is necessary. As a first step, the dose rate at a point $10.8 \mu \mathrm{m}$ from an effectively infinite plane source can be considered, and the dose rate is given by:

$$
\mathrm{D}_{\alpha}(\mathrm{h})=\frac{1.07}{\varrho}\left[\operatorname{Aln}\left(\frac{\mathrm{R}_{\alpha}}{\mathrm{h}}\right)+\frac{\mathrm{B}}{2}\left(\mathrm{R}_{\alpha}^{2}-\mathrm{h}^{2}\right)\right] \mu \mathrm{rad} \mathrm{h}^{-1}\left(\mathrm{pCi} \mathrm{cm}^{-2}\right)^{-1}
$$

where $\varrho$ is the density of the tissue, here taken to be $1 \mathrm{~g} \mathrm{~cm}^{-3}$,

$$
\left.\begin{array}{l}
\mathrm{A}=8.6 \times 10^{2} \mathrm{MeV} \mathrm{cm}^{-1} ; \\
\mathrm{B}=1.02 \times 10^{8} \mathrm{MeV} \mathrm{cm}^{-3} ; \\
\mathrm{R}_{\alpha}=4.02 \times 10^{-3} \mathrm{~cm}
\end{array}\right\} \begin{aligned}
& { }^{241} \mathrm{Am}(5.57 \mathrm{MeV}) \\
& { }^{2}
\end{aligned}
$$

and $h=1.08 \times 10^{-3} \mathrm{~cm}$ in the present example (Woodhead, 1979).

The total dose over the mean survival period is given by

$$
\left.\mathrm{D}_{\alpha}\left(\mathrm{h}, \mathrm{T}_{\mathrm{s}}\right)=\int_{0}^{\mathrm{T}_{\mathrm{s}}} \mathrm{D}_{\alpha}(\mathrm{h}) \times 24\left(1-\exp \frac{-0.693 \mathrm{t}}{\mathrm{t}_{1 / 2}}\right) \mathrm{dt} \mathrm{rad}(\mathrm{pCi} \mathrm{cm})^{-2}\right)^{-1} .
$$

These expressions give

$$
D_{\alpha}\left(1.08 \times 10^{-3}\right)=2.43 \mathrm{rad} \mathrm{h}^{-1} \text { and } D_{\alpha}\left(1.08 \times 10^{-3}, \mathrm{~T}_{\mathrm{s}}\right)=3620 \mathrm{rad}
$$

for experiment I, and

$$
\mathrm{D}_{\alpha}\left(1.08 \times 10^{-3}\right)=0.28 \mathrm{rad} \mathrm{h}^{-1} \text { and } \mathrm{D}_{\alpha}\left(1.08 \times 10^{-3}, \mathrm{~T}_{\mathrm{s}}\right)=600 \mathrm{rad}
$$

for experiment II.

These values are probably reasonable estimates for the radioactivity assumed to be uniformly spread over parts of the exoskeleton with a relatively large radius of curvature $(\geq 0.5 \mathrm{~mm})$, i.e. the body surface and the lateral plates. For parts of the exoskeleton with a small radius of curvature ( $\leqslant 0.5 \mathrm{~mm}$ ), i.e, the legs, antennae etc, these values probably represent underestimates because increasing curvature increases the contaminated surface area within range of the target. It is not possible to generate an analytical expression for the dose rate at an off-axis point encloded inside a long cylindrical source, but an indication of the effect of increasing curvature on the dose rate at a point $10.8 \mu \mathrm{m}$ from the contaminated surface is available for a spherical shell source since 


$$
\left.\mathrm{D}_{\alpha}(\mathrm{h}, \mathrm{r})=\frac{1.07}{\varrho} \cdot \frac{\mathrm{r}}{\mathrm{r}-\mathrm{h}}\left\{\mathrm{Aln}\left(\frac{2 \mathrm{r}-\mathrm{h}}{\mathrm{h}}\right)+\frac{\mathrm{B}}{2}\left[(2 \mathrm{r}-\mathrm{h})^{2}-\mathrm{h}^{2}\right]\right\} \mu \mathrm{rad} \mathrm{h}^{-1}(\mathrm{pCi} \mathrm{cm})^{-2}\right)^{-1}
$$

for $2 \mathrm{r}-\mathrm{h} \leqslant \mathrm{R}_{\alpha}$ and

$$
\mathrm{D}_{\alpha}(\mathrm{h}, \mathrm{r})=\frac{1.07}{\varrho} \cdot \frac{\mathrm{r}}{\mathrm{r}-\mathrm{h}}\left[\mathrm{Aln}\left(\frac{\mathrm{R}_{\alpha}}{\mathrm{h}}\right)+\frac{\mathrm{B}}{2}\left(\mathrm{R}_{\alpha}^{2}-\mathrm{h}^{2}\right)\right] \mu \mathrm{rad} \mathrm{h}^{-1}\left(\mathrm{pCi} \mathrm{cm}^{-2}\right)^{-1}
$$

for $2 \mathrm{r}-\mathrm{h}>\mathrm{R}_{\alpha}$

(Woodhead, 1979).

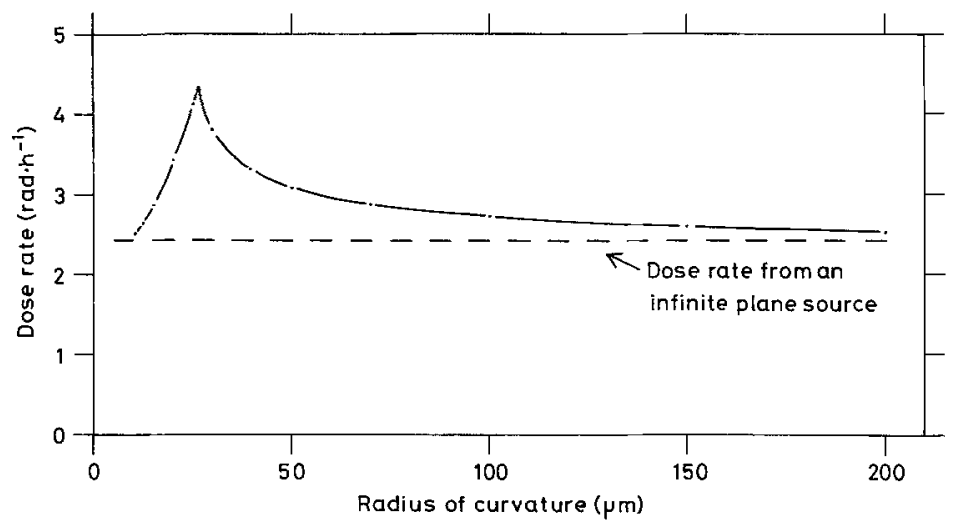

Fig. 12. Dose rate at an internal point $10.8 \mu \mathrm{m}$ from the surface of spherical shells of different radii uniformly contaminated with ${ }^{241} \mathrm{Am}$ at $1.2 \times 10^{3} \mathrm{pCi} \mathrm{cm}^{-2}$

As expected, the second expression reduces to that for an infinite plane source, as given above, for $r \rightarrow \infty$. The derived values of the dose rate are plotted in Figure 12, from which it can be seen that the dose rate at a point from the curved surface is always greater than that at an equivalent point from a plane surface. The dose rate at an equivalent point for the cylindrical surface will lie between the extreme values given by the spherical and plane cases because the cylinder has curvature about a single axis compared with three for the sphere. Thus estimates based on a plane source configuration are only likely to

\begin{tabular}{|c|c|c|}
\hline & Experiment 1 & Experiment II \\
\hline $\begin{array}{l}\text { Dose rate to soft tissue from } \\
\text { accumulated radioactivity } \\
\text { Total absorbed dose to soft tissue from accumulated } \\
\text { radioactivity over the mean survival period }\end{array}$ & $\begin{array}{l}0.77 \mathrm{rad} \mathrm{h}^{-1} \\
1150 \mathrm{rad}\end{array}$ & $\begin{array}{l}0.08 \mathrm{rad} \mathrm{h}^{-1} \\
178 \mathrm{rad}\end{array}$ \\
\hline $\begin{array}{l}\text { Dose rate to epidermal cell nucleus from } \\
\text { (a) radioactivity on the exoskeleton } \\
\text { (b) radioactivity in soft tissue } \\
\text { (c) radioactivity in the water } \\
\text { Total dose rate from the three sources } \\
\text { Total absorbed dose to epidermal cell nucleus from } \\
\text { the three sources over the mean survival period. }\end{array}$ & $\begin{array}{l}2.43 \mathrm{rad} \mathrm{h}^{-1} \\
0.59 \mathrm{rad} \mathrm{h}^{-1} \\
1.68 \times 10^{-3} \mathrm{rad} \mathrm{h}^{-1} \\
3.02 \mathrm{rad} \mathrm{h}^{-1} \\
\\
4500 \mathrm{rad}\end{array}$ & $\begin{array}{l}0.28 \mathrm{rad} \mathrm{h}^{-1} \\
0.06 \mathrm{rad} \mathrm{h}^{-1} \\
12.41 \times 10^{-4} \mathrm{rad} \mathrm{h}^{-1} \\
0.34 \mathrm{rad} \mathrm{h}^{-1} \\
740 \mathrm{rad}\end{array}$ \\
\hline
\end{tabular}

Table 2. Summary of dose rate and total absorbed dose estimates 
err significantly on the low side for those appendages with diameters in the range $40 \mu \mathrm{m}$ to $100 \mu \mathrm{m}$.

The target cell nucleus already considered will also be irradiated by $\alpha$-particles originating in the water and in the soft tissue. The required expression is for the dose rate at $10.8 \mu \mathrm{m}$ from a thick plane source, ie.

$\mathrm{D}_{\alpha}(\mathrm{h}, \infty)=\frac{1.07}{\varrho}\left[\left(\mathrm{A}+\frac{\mathrm{BR}_{\alpha}^{2}}{2}\right)\left(\mathrm{R}_{\alpha}-\mathrm{h}\right)-\mathrm{Ahln}\left(\frac{\mathrm{R}_{\alpha}}{\mathrm{h}}\right)-\frac{\mathrm{B}}{6}\left(\mathrm{R}_{\alpha}^{3}-\mathrm{h}^{3}\right)\right] \mu \mathrm{rad} \mathrm{h}^{-1}\left(\mathrm{pCi} \mathrm{g}^{-1}\right)^{-1}$

for the activity in the water and for the activity in soft tissue

$$
\mathrm{D}_{\alpha \text { tiss. }}(\mathrm{h}, \infty)=\mathrm{D}_{\alpha}(\infty)-\mathrm{D}_{\alpha}(\mathrm{h}, \infty) \mu \mathrm{rad} \mathrm{h}^{-1}\left(\mathrm{pCi} \mathrm{g}^{-1}\right)^{-1} \text {, }
$$

where $\varrho, A, B$ and $R_{\alpha}$ have the values used previously. The dose rate and total dose to the epidermal cell nucleus from activity in the water are

$$
\mathrm{D}_{\alpha}(\mathrm{h}, \infty)=1.68 \times 10^{-3} \mathrm{rad} \mathrm{h}^{-1} \text { and } \mathrm{D}_{\alpha}\left(\mathrm{h}, \infty, \mathrm{T}_{\mathrm{s}}\right)=2.50 \mathrm{rad}
$$

for experiment I, and

$$
\mathrm{D}_{\alpha}(\mathrm{h}, \infty)=2.41 \times 10^{-4} \mathrm{rad} \mathrm{h}^{-1} \text { and } \mathrm{D}_{\alpha}\left(\mathrm{h}, \infty, \mathrm{T}_{\mathrm{s}}\right)=0.51 \mathrm{rad}
$$

for experiment II.

Similarly, the dose rate and total absorbed dose to the epidermal cell nucleus from the activity in the soft tissue are

$$
\mathrm{D}_{\alpha \text { tiss. }}(\mathrm{h}, \infty)=0.59 \mathrm{rad} \mathrm{h}^{-1} \text { and } \mathrm{D}_{\alpha \text { tiss. }}\left(\mathrm{h}, \infty, \mathrm{T}_{\mathrm{s}}\right)=873 \mathrm{rad}
$$

for experiment $I$, and

$$
\mathrm{D}_{\alpha \text { tiss. }}(\mathrm{h}, \infty)=0.06 \mathrm{rad} \mathrm{h}^{-1} \text { and } \mathrm{D}_{\alpha \text { tiss. }}\left(\mathrm{h}, \infty, \mathrm{T}_{\mathrm{s}}\right)=135 \mathrm{rad} \text {. }
$$

The results of the calculations are summarized in Table 2.

\section{DISCUSSION}

Fowler et al. (1975) for plutonium (+6) gave the percentage contained in moults of the shrimp, Lysmata sedicaudata, as 92-100 and as 70-100 in the euphausiid, Meganyctiphanes norvegica (Fowler \& Heyraud, 1976). In the lobster $89.5 \%$ of the total body burden of plutonium was found to be associated with the calcified exoskeleton (Ward, 1966). Similar high proportions were established to be associated with the exoskeleton in Cancer pagurus and Lysmata sedicaudata in uptake experiments with the transuranic element neptunium (Guary \& Fowler, 1978). In Gammarus duebeni the percentage fixed on the exoskeleton has been estimated to be $61 \%$ (range: $30-94 \%$ ). The measured activities of the exuviae ( $n=17$ ) have been related both to the activities of gammarids on days before and on days of moult. The mean value is given. From these and the abovecited findings it has to be concluded that the larger fraction of the total americium body burden is associated with the exoskeleton.

Although at $\mathrm{pH} 6.5$ an increase in water activity due to desorption from the experimental system was seen to occur, the body burden of the gammarid remained unchanged. It thus seems that the uptake mechanism by which Gammarus obtains the 
major part of its body activity must be such as to strongly protect the activity associated with the exoskeleton in the range of $\mathrm{pH}^{8}$ 8.0-6.5. Based on the observation that the americium body burden remains constant with changing environmental conditions it would appear that the establishment of a concentration factor is meaningless. Work undertaken on point 1 (see introduction) of the present study on the development of methods to characterize actinide chemical speciation has further shown that concentration factors vary greatly ( 2 orders of magnitude difference) depending on the source term of the actinides (Murray et al., 1979). The present authors thus propose that the concept of concentration factors should be re-examined and in future be defined for actinides in terms of environmental and chemical parameters. The resulting factor should represent the bioavailable fraction of these elements.

Ward (1966) observed that plutonium is accumulated in the lobster at a rather high rate by the calcifying shell, a phenomenon that was also observed for gammarids. Murray et al. (1978) found higher uptake in specimens that had moulted 1 day before the start of an experiment as compared with those which had been exposed in a later phase within their moulting cycles. In the present work it has been shown that uptake is rapid and higher concentration factors are reached in juvenile specimens.

With the exception of a short communication by Pittock \& Calkins (1973) the authors are not aware of any published material on the effects of americium on aquatic organisms. A few references, however, are given by Blaylock \& Trabalka (1978) and Till (1978) for plutonium. In studies on the effect of chemical toxicity on eggs of carp and fathead minnows, using very low specific activity plutonium it was found that the metal concentration of ${ }^{244} \mathrm{Pu}$ necessary to cause a deleterious effect had to be many orders of magnitude greater $\left(\mathrm{mg} \mathrm{l}^{-1}\right)$ than the metal concentration of ${ }^{238} \mathrm{Pu}$ required to achieve a radiotoxic effect (Till et al, 1976). On the basis of these findings we assume that the effects observed in the present experiment are mainly due to irradiation by $5.57 \mathrm{MeV} \alpha$ particles.

Investigations carried out by Hoppenheit $(1969,1972,1973)$ on Gammarus duebeni using acute X-irradiation indicated that doses below 1000 Röntgen only produce sublethal effects and it was found that doses of $220 \mathrm{R}$ or lower have a "stimulating" effect distinguishable by the higher survival rate of the irradiated specimens. It cannot be excluded that the difference in survival rates in the second irradiation experiment may be the consequence of a similar process. Work undertaken by Pittock \& Calkins (1973) on protozoa irradiated with americium-241 alpha particles offers evidence that damage from high LET radiation is potentially repairable.

The dose rate and total dose values given in Table 2 are, of course, subject to many qualifications and should not be taken as any more than indications of the magnitudes of the absorbed doses which may have been accumulated during the course of the experiments. The greatest improvement in the accuracy of the estimates could be gained from a better knowledge of the magnitude and geometry of the source of radiation relative to specific target cells, tissues or organs. However, since the greater part of the body burden is associated with the extremely complex outer surface of the exoskeleton it will not be easy to make large improvements in the accuracy of the estimates.

In addition it should be noted that the determination of the biologically effective dose to the soft tissue or the epidermal cells requires the absorbed doses given in Table 2 to be increased by a factor of 20 (the quality factor recommended by ICRP for $\alpha$ - 
particles). Such a re-evaluation is necessary if reasonable comparisons are to be made between the results presented here and the effects noted after X- or $\gamma$-irradiation.

The concentrations of ${ }^{241} \mathrm{Am}$ used in these experiments are several orders of magnitude higher than those which could occur in the marine environment on the grounds of public radiation protection. Future studies will investigate the possible effects of ${ }^{241} \mathrm{Am}$ concentrations which are more relevant to environmental concerns.

Acknowledgements. The authors thank Dr. H.-P. Bulnheim for placing at their disposal material for estimating parameters of the body structure of the species under investigation, Mrs. I. Ziehr and Miss R. Kleinfeld for careful technical assistance as well as the latter for drawing the figures.

\section{LITERATURE CITED}

Blaylock, B. G. \& Trabalka, J. R., 1978. Evaluating the effects of ionizing radiation on aquatic organisms. - Adv. radiat. Biol. 7, 103-152.

Fowler, S. \& Heyraud, M., 1976. Flux of plutonium through marine biota. - P. v. Réun. Commn int. Explor. scient. Mer Méditerr. 23 (7), 161-162.

Fowler, S., Heyraud, M. \& Beasley, T. M., 1975. Experimental studies on plutonium kinetics in marine biota. In: Impacts of nuclear releases into the aquatic environment. IAEA, Vienna, $157-177$.

Guary, J.-C., \& Fowler, S. W., 1978. Uptake from water and tissue distribution of neptunium-237 in crabs, shrimp and mussels. - Mar. Pollut. Bull. 9, 331-334.

Hoppenheit, M., 1969. Strahlenbiologische Untersuchungen an Gammariden (Crustacea, Amphipoda). - Helgoländer wiss. Meeresunters. 19, 163-204.

Hoppenheit, M., 1972. Wirkungen einer einmaligen Röntgenbestrahlung auf die Fortpflanzung der Weibchen von Gammarus duebeni (Crustacea, Amphipoda). - Helgoländer wiss. Meeresunters. $23,467-484$.

Hoppenheit, M., 1973. Effects on fecundity and fertility of single sub-lethal X-irradiation of Gammarus duebeni females. In: Radioactive contamination of the marine environment. IAEA, Vienna, 479-486.

Kaufmann, H., 1966. Ein einfaches Verfahren zur Auswertung von Überlebenskurven bei tödlich verlaufenden Erkrankungen. - Strahlentherapie 130, 509-527.

Murray, C. N. \& Fukai, R., 1975. Adsorption-desorption characteristics of plutonium and americium with sediment particles in the estuarine environment. In: Impacts of nuclear releases into the aquatic environment. IAEA, Vienna, 179-192.

Murray, C. N., Hoppenheit, M. \& Rade, H., 1978. Accumulation of americium 243 in selected brackish and marine invertebrates. - Helgoländer wiss. Meeresunters. 31, 34-54.

Murray, C. N., Avogadro, A. \& Lazzari, G., 1979. The distribution of actinides in a freshwater microcosm $;$ comparison of simulated input sources. - Second International Symposium of Radioecology, Cadarache, June 1979 (in press).

Pittock, J. W. \& Calkins, J., 1973. UV reactivation of protozoa irradiated with americium 241 alpha particles. - Radiat. Res. 55, 597.

Sachs, L., 1974. Angewandte Statistik. Springer, Berlin, 545 pp.

Till, J. E., 1978. The effect of chronic exposure to ${ }^{238} \mathrm{Pu}$ (IV) citrate on the embryonic development of carp and fathead minnow eggs. - Health Phys. 34, 333-343.

Till, J. E., Kaye, S. V. \& Trabalka, J. R., 1976. The toxicity of uranium and plutonium to the developing embryos of fish. Oak Ridge National Laboratory, Oak Ridge, 189 pp. (ORNL-5160).

Ward, E. E., 1966. Uptake of plutonium by the lobster Homarus vulgaris. - Nature, Lond. 209, 625-626.

Woodhead, D. S., 1979. Methods of dosimetry for aquatic organisms. - Tech. Rep. Ser. IAEA, Vienna, 190, 43-96. 